\title{
Dietary vitamin B6 modulates the gene expression of myokines, Nrf2-related factors, myogenin and HSP60 in the skeletal muscle of rats
}

\author{
SOFYA SUIDASARI, SHINJI URAGAMI, NORIYUKI YANAKA and NORIHISA KATO \\ Graduate School of Biosphere Science, Hiroshima University, Higashi-Hiroshima 739-8528, Japan
}

Received October 12, 2015; Accepted February 24, 2017

DOI: $10.3892 / \mathrm{etm} .2017 .4879$

\begin{abstract}
Previous studies have suggested that vitamin B6 is an ergogenic factor. However, the role of dietary vitamin B6 in skeletal muscle has not been widely researched. The aim of the present study was to investigate the effects of dietary vitamin B6 on the gene expression of 19 myokines, 14 nuclear factor erythroid 2-related factor 2 (Nrf2)-regulated factors, 8 myogenesis-related factors and 4 heat shock proteins (HSPs), which may serve important roles in skeletal muscles. Rats were fed a diet containing 1 (marginal vitamin B6 deficiency), 7 (recommended dietary level) or $35 \mathrm{mg} / \mathrm{kg}$ of pyridoxine $(\mathrm{PN}) \mathrm{HCl} /$ for 6 weeks. Gene expressions were subsequently analysed using reverse transcription-quantitative polymerase chain reaction. Food intake and growth were
\end{abstract}

Correspondence to: Professor Norishisa Kato, Graduate School of Biosphere Science, Hiroshima University, 1-4-4 Kagamiyama, Higashi-Hiroshima 739-8528, Japan

E-mail: nkato@hiroshima-u.ac.jp

Abbreviations: PLP, pyridoxal 5'-phosphate; PN, pyridoxine; IL, interleukin; F, forward; R, reverse; SPARC, secreted protein acidic and rich in cysteine; GDF, growth differentiation factor; LIF, leukemia inhibitory factor; RARRES1, retinoic acid receptor responder (tazarotene induced) 1; OSM, oncostatin M; FGF, fibroblast growth factor; GDNF, glial cell derived neurotrophic factor; LTBP2, latent-transforming growth factor $\beta$-binding protein 2; CHI311, chitinase-3-like protein 1; SERP4, septin 4; Metrn, meteorin; HO, heme oxygenase; SOD, superoxide dismutase; GPX, glutathione peroxidase; Nrf, nuclear respiratory factor; GST, glutathione S-transferase; Keap1; kelch-like ECH associated protein 1; PGCla, peroxisome proliferator-activated receptor gamma coactivator 1 alpha; Imp-11, importin 11; Trx2, thioredoxin reductase-2; Nqo1, NADPH quinone oxidoreductase 1; UBE2E3, ubiquitin-conjugation enzyme E2 E3; GCLC, glutamate-cysteine ligase catalytic subunit; MuRf1, muscle ring-finger protein-1; Myf, myogenic factor; MyoD1, myogenic differentiation 1; RPB3, RNA polymerase B3; Sp1, specificity protein; HSP, heat shock protein; Nrxn, neurexin; Ntn, netrin

Key words: vitamin B6, myokine, nuclear factor (erythroidderived 2)-like 2, myogenin, heat shock protein 60 , gastrocnemius muscle, rats unaffected by this dietary treatment. The rats in the 7 and $35 \mathrm{mg} / \mathrm{kg}$ PN HCl groups exhibited a significant increase in the concentration of pyridoxal 5'-phosphate in the gastrocnemius muscle compared with the $1 \mathrm{mg} / \mathrm{kg} \mathrm{PN} \mathrm{HCl}$ diet $(\mathrm{P}<0.01)$. The expressions of myokines, such as IL-7, IL-8, secreted protein acidic and rich in cysteine, IL-6, growth differentiation factor 11, myonectin, leukaemia inhibitory factor, apelin and retinoic acid receptor responder (tazarotene induced) 1 , the expression of Nrf2 and its regulated factors, such as heme oxygenase 1 , superoxide dismutase 2, glutathione peroxidase 1 and glutathione $\mathrm{S}$-transferase, and the expression of myogenin and HSP60 were significantly elevated in the $7 \mathrm{mg} / \mathrm{kg} \mathrm{PN} \mathrm{HCl}$ group compared with the $1 \mathrm{mg} / \mathrm{kg}$ $\mathrm{PN} \mathrm{HCl}$ diet $(\mathrm{P}<0.05)$. No significant differences in levels of these genes were observed between the 35 and $1 \mathrm{mg} / \mathrm{kg}$ $\mathrm{PN} \mathrm{HCl}$, with the exception of GDF11 and myonectin, whose expressions were significantly increased in the $35 \mathrm{mg} / \mathrm{kg} \mathrm{PN}$ $\mathrm{HCl}(\mathrm{P}<0.05)$. Notably, the majority of gene expressions that were affected responded to dietary supplemental vitamin B6 in a similar manner. The results suggest that compared with the marginal vitamin B6 deficiency, the recommended dietary intake of vitamin B6 upregulates the gene expression of a number of factors that promote the growth and repair of skeletal muscle.

\section{Introduction}

Pyridoxal 5'-phosphate (PLP), the active form of vitamin B6, is known to modulate important metabolisms in the body (1). Skeletal muscle is the major source of PLP in the body (1). Some biological functions of vitamin B6 have been reported to be associated with fuel metabolism during exercise (2). It has been suggested that the exercise-related function of vitamin B6 is at least in part associated with the breakdown of muscle glycogen (2). Glycogen phosphorylase is the enzyme responsible for the release of glucose-1-phosphate from muscle glycogen, and PLP is a cofactor for this enzyme (2). Vitamin B6 deficiency has been reported to decrease the activity and amount of muscle phosphorylase (3). Rats fed high levels of vitamin B6 have previously exhibited elevated concentrations of muscle phosphorylase (4). Furthermore, it is thought that vitamin B6 may have a favourable effect on the skeletal muscle, as a previous case study demonstrated that vitamin B6 supplementation was beneficial for the treatment of McArdle 
disease, a glycogenetic myopathy (5). Exercise has also been reported to increase blood PLP levels (6).

The recent discovery of several myokines has established a new paradigm of muscle as an endocrine organ (7). Myokines are released during muscle contraction, for example during exercise (7). Some known contraction-regulated myokines are interleukin (IL)-6, IL-7, IL-15, brain-derived neuro factor, fibroblast growth factor 21 (FGF21), follistatin-like 1, leukaemia inhibitory factor (LIF), vascular endothelial growth factor, irisin, myostatin and myonectin (7). Myokines have been reported to serve important roles in biological homeostasis, being involved in energy metabolism, angiogenesis and myogenesis (8). They are also considered to be putative preventive factors against chronic diseases such as type II diabetes $(9,10)$. Some studies have suggested that myokines serve pivotal roles in the communication between skeletal muscles and other tissues, such as adipose tissues and liver and pancreatic cells (10-12).

The transcription factor nuclear factor erythroid 2-related factor 2 (Nrf2) regulates oxidative defences by inducing the expression of cytoprotective genes (13). Nrf2 induces these genes primarily by binding the antioxidant response element (ARE) in the promoter of the genes that code for anti-oxidative enzymes (13). Nrf2/ARE signalling is activated by acute exercise stress in the myocardium (14). Several previous studies have suggested that the role of Nrf2 goes beyond antioxidant mechanisms $(15,16)$. Al-Sawaf et al $(16)$ reported that Nrf2 regulated myogenic regulatory factor (Mrf) expression and that Nrf2-knockout retarded skeletal muscle regeneration after injury. Heat shock proteins (HSPs) have also been reported to have a cytoprotective role in skeletal muscles (17). Furthermore, it has been reported that exercise induces the expression of HSPs in skeletal muscle, heart and liver (18).

In the present study, the mRNA of myokines, Nrf2-related factors, myogenic factors and HSPs in the gastrocnemius muscles of rats that were fed a low vitamin B6 diet with and without vitamin B6 supplementation were analysed. Further analyses using DNA microarrays were also performed.

\section{Materials and methods}

Animals and diets. A total of 24 male 3-week-old SpragueDawley rats (Charles River Laboratories Japan, Inc., Tokyo, Japan) were purchased and maintained in accordance with the Guide for the Care and Use of Laboratory Animals established by Hiroshima University (Higashi-Hiroshima, Japan). The rats were housed in metal cages in a temperature-controlled room $\left(24 \pm 1^{\circ} \mathrm{C}\right)$ with a $12 \mathrm{~h}$ light/dark cycle (lights on from 08:00-20:00) at a humidity of 40-50\%. The rats had free access to food and deionized water. The basal diet comprised the components as described previously (19). Pyridoxine (PN) HCl (Nacalai Tesque, Inc., Kyoto, Japan) was supplemented to the basal diet at 1,7 , or $35 \mathrm{mg} \mathrm{PN} \mathrm{HCl}$ per $\mathrm{kg}$ of food. The level of $\mathrm{PN} \mathrm{HCl}$ diet recommended in the AIN-93 diet is $7 \mathrm{mg} / \mathrm{kg} \mathrm{PN} \mathrm{HCl}$ (20). Meanwhile, $1 \mathrm{mg} / \mathrm{kg}$ $\mathrm{PN} \mathrm{HCl}$ diet is reported to be the minimum level required to prevent growth depression caused by vitamin B6 deficiency (21). Following one week of commercial nonpurified diet (MF basic food; Oriental Yeast Co., Ltd., Tokyo, Japan)
24 rats (mean weight, $70 \mathrm{~g}$ for all three groups) were divided randomly into 3 groups $(\mathrm{n}=8)$ receiving 1,7 or $35 \mathrm{mg} \mathrm{PN}$ $\mathrm{HCl} / \mathrm{kg}$ diet for 6 weeks. At the end of this period, rats were sacrificed by decapitation following anaesthesia with inhalation exposure of diethyl ether (>99.5\%, Wako Pure Chemical Industries, Ltd., Osaka, Japan) for 20-30 sec in total in the desiccator to reduce the suffering. The gastrocnemius muscle was quickly dissected, and immediately homogenized in Qiagen lysis buffer for RNA isolation (Qiagen AB, Sollentuna, Sweden). Ethical approval was granted (approval no. C10-20) by the Ethics Committee of Hiroshima University (Higashi-Hiroshima, Japan).

Gastrocnemius muscle PLP. PLP levels in the gastrocnemius muscle were measured as previously described (19). Briefly, PLP from skeletal muscle was extracted using ice-cold $1 \mathrm{M}$ perchloric acid. The samples were adjusted to $\mathrm{pH} 7.5$ with $5 \mathrm{M}$ potassium hydroxide. Samples were then, centrifuged at $12,000 \mathrm{x} \mathrm{g}$ at $4^{\circ} \mathrm{C}$ for $10 \mathrm{~min}$ and the supernatant was collected. For the extraction of PLP, $30 \mu \mathrm{l}$ of $0.1 \mathrm{M}$ potassium cyanide was added to $400 \mu \mathrm{l}$ supernatant and agitated at $50^{\circ} \mathrm{C}$ for $3 \mathrm{~h}$. The $\mathrm{pH}$ was readjusted to 3.5 with $1 \mathrm{M} \mathrm{HCl}$. Then the samples were left to stand at $25^{\circ} \mathrm{C}$ for $24 \mathrm{~h}$. The resulting solution of PLP was mixed with deionized water. Prior to injection into an HPLC line, all of the solutions were passed through a $0.45 \mu \mathrm{m}$ pore size membrane filter, and analyzed by a HPLC device with a fluorometric detector as previously described (22). For the determination of PLP, a fluorescence measurement was set at emission wavelength of $420 \mathrm{~nm}$ with an excitation wavelength of $320 \mathrm{~nm}$.

DNA microarray analysis. Pooled RNAs from the gastrocnemius muscle of each group rats $(n=8)$ were subjected to complementary RNA synthesis for a DNA microarray analysis. Cyanine-3 labelled cRNA was prepared from $100 \mathrm{ng}$ RNA using the One-Color Low Input Quick Amp labelling kit (Agilent Technologies, Inc., Santa Clara, CA, USA) according to the manufacturer's protocol. All procedures of hybridization, slide, and scanning were carried out according to the manufacturer's protocol (Agilent Technologies, Inc.). The data were analysed by GeneSpring software version 12.6.1 (Agilent Technologies, Inc.).

mRNA analysis. The Qiagen Midi kit (Qiagen AB) was used to isolate total RNA (500 and 1,200 $\mathrm{ng} / \mu \mathrm{l}$ ) from rat gastrocnemius muscle, which was subsequently prepared according to the manufacturers protocol. In the purification of total RNA with this kit, silica-gel membrane, spin-column technology was used to efficiently remove the genomic DNA. The reverse transcriptase reaction was carried out with $1 \mu \mathrm{g}$ total RNA as a template to synthesize cDNA using ReverTra Ace (Toyobo, Co., Ltd., Osaka, Japan) and random hexamers (TaKaRa Bio, Inc., Otsu, Japan) in a final reaction volume of $20 \mu \mathrm{l}$, according to the manufacturer's protocol. Quantitative polymerase chain reaction (qPCR) was performed with a StepOne $^{\text {TM }}$ Real-Time PCR System (Applied Biosystems; Thermo Fisher Scientific, Inc.) using the Thunderbird SYBR qPCR Mix (Toyobo, Co., Ltd.). For qPCR analysis, $10 \mu \mathrm{l}$ SYBR-Green (containing DNA polymerase), forward and reverse primer $(0.8 \mu \mathrm{M}$ each $)$, and $1,000 \mathrm{ng}$ cDNA were 
contained in a final reaction volume of $20 \mu 1$. All primers were purchased from Greiner Bio-One, Ltd. (Kremsmünster, Austria) and are displayed in Table I. The cycling parameters were as follows: Initial step at $90^{\circ} \mathrm{C}$ for $10 \mathrm{sec}$, followed by 40 cycles at $90^{\circ} \mathrm{C}$ for $5 \mathrm{sec}, 60^{\circ} \mathrm{C}$ for $10 \mathrm{sec}$ and $72^{\circ} \mathrm{C}$ for $10 \mathrm{sec}$. The mRNA level was normalized to that of GAPDH, and all reactions were performed at least in duplicate. Analysis of relative gene expression levels was performed using the following formula: $2^{-\Delta \Delta \mathrm{Cq}}$ with $\Delta \Delta \mathrm{CT}=\mathrm{Cq}$ (target gene) $-\mathrm{Cq}$ (control) (23).

Statistical analysis. Data are expressed as the mean \pm standard error of the mean. Tukey-Kramer HSD test was used to compare means following one way analysis of variance. Data analysis was performed using Excel Statistics 2010 for Windows (Microsoft Corporation, Redmond, WA, USA). Some data underwent regression analysis and the correlation coefficient was calculated. $\mathrm{P}<0.05$ was considered to indicate a statistically significant difference.

\section{Results}

Food intake, body weight, muscle weight and muscle PLP. Dietary manipulation had no significant effect on food intake, final body weight and weight of the gastrocnemius muscle from one leg (Table II). Muscle PLP concentrations in the 7 and $35 \mathrm{mg} / \mathrm{kg} \mathrm{PN} \mathrm{HCl}$ groups were significantly higher than those in the $1 \mathrm{mg} / \mathrm{kg}$ group (Table II). No significant difference was observed in muscle PLP concentrations between the 7 and $35 \mathrm{mg} / \mathrm{kg} \mathrm{PN} \mathrm{HCl}$ groups.

Effect of dietary vitamin B6 on the gene expressions in the gastrocnemius muscle of rats. Among the 19 myokines genes that were examined, 9 genes were significantly affected by dietary vitamin B6 (Table III; P<0.05). Among these genes, the expressions of IL-7, IL-8, protein acidic and rich in cysteine (SPARC), IL-6, growth differentiation factor (GDF)11, myonectin, LIF, apelin and retinoic acid receptor responder (tazarotene induced) 1 (RARRES1) were significantly higher in the $7 \mathrm{mg} / \mathrm{kg}$ PN $\mathrm{HCl}$ group $(+107,+105,+92,+77,+75,+65,+62,+61$ and $+53 \%$, respectively; $\mathrm{P}<0.05$ ) compared with the $1 \mathrm{mg} / \mathrm{kg} \mathrm{PN} \mathrm{HCl}$ group. No significant differences were observed in levels of these genes between the 1 and $35 \mathrm{mg} / \mathrm{kg} \mathrm{PN} \mathrm{HCl}$ groups, with the exception of GDF11 and myonectin, whose expressions were significantly increased in the $35 \mathrm{mg} / \mathrm{kg} \mathrm{PN} \mathrm{HCl}$ group compared with the $1 \mathrm{mg} / \mathrm{kg} \mathrm{PN} \mathrm{HCl}$ group (Table III; $\mathrm{P}<0.05$ ). The expressions of other myokines were not significantly affected by the dietary vitamin B6 levels (Table III).

Dietary vitamin B6 also had a significant effect on the expression of some genes associated with mitochondrial function and genes associated with Nrf2 in the gastrocnemius muscle of rats; among the 14 genes evaluated, the expressions of heme oxygenase (HO)-1, superoxide dismutase (SOD)2, glutathione peroxidase (GPX)1, Nrf2 and glutathione S-transferase (GST) were significantly elevated in the $7 \mathrm{mg} / \mathrm{kg}$ $\mathrm{PN} \mathrm{HCl}$ group compared with the $1 \mathrm{mg} / \mathrm{kg} \mathrm{PN} \mathrm{HCl}$ group (Table IV; $\mathrm{P}<0.05$ ). No significant differences in expressions of these genes were observed between the 1 and $35 \mathrm{mg} / \mathrm{kg}$ PN $\mathrm{HCl}$ groups. The expressions of all other genes evaluated were unaffected (Table IV).
Table I. Sequences of primers used for reverse transcription-quantitative polymerase chain reaction.

\begin{tabular}{|c|c|c|}
\hline Gene & Direction & Sequence $\left(5^{\prime}-3^{\prime}\right)$ \\
\hline \multirow[t]{2}{*}{ GAPDH } & $\mathrm{F}$ & TGACAACTCCCTCAAGATTGTC \\
\hline & $\mathrm{R}$ & GGCATGGACTGTGGTCATGA \\
\hline \multirow[t]{2}{*}{ IL-7 } & $\mathrm{F}$ & TTTGGAATTCCTCCCCTGAT \\
\hline & $\mathrm{R}$ & TCATCAGCACACTCCCAAAG \\
\hline \multirow[t]{2}{*}{ IL-8 } & $\mathrm{F}$ & GAAGATAGATTGCACCGA \\
\hline & $\mathrm{R}$ & CATAGCCTCTCACACATTTC \\
\hline \multirow[t]{2}{*}{ SPARC } & $\mathrm{F}$ & GGGCAGACCAATACCTCACTA \\
\hline & $\mathrm{R}$ & CCGACCATTCCTTCCGTTG \\
\hline \multirow[t]{3}{*}{ IL-6 } & $\mathrm{F}$ & СССААСТТССААТGСТСТССТА \\
\hline & $\mathrm{R}$ & GCACACTGAGTTTGCCGAATA \\
\hline & & GACC \\
\hline \multirow[t]{2}{*}{ GDF11 } & $\mathrm{F}$ & AGCATCAAGTCGCAGATCCT \\
\hline & $\mathrm{R}$ & CTTATGACCGTCTCGGTGGT \\
\hline \multirow[t]{2}{*}{ Myonectin } & $\mathrm{F}$ & TGTTGTTGAAAGGTGCGGTA \\
\hline & $\mathrm{R}$ & TCTCAAGCTCCTGGGTGACT \\
\hline \multirow[t]{2}{*}{ LIF } & $\mathrm{F}$ & AAGTACCATGTGGGCCATGT \\
\hline & $\mathrm{R}$ & GGACCACCGCACTAATGACT \\
\hline \multirow[t]{2}{*}{ Apelin } & $\mathrm{F}$ & GGCTAGAAGAAGGCAACATGC \\
\hline & $\mathrm{R}$ & CCGCTGTCTGCGAAATTTCCT \\
\hline \multirow[t]{2}{*}{ RARRES 1} & $\mathrm{~F}$ & GCTGCACTTCCTCAАСTTCC \\
\hline & $\mathrm{R}$ & TGTGCTAAACACCAGGTCCA \\
\hline \multirow[t]{2}{*}{ OSM } & $\mathrm{F}$ & GAACATCCAAGGGATCAGGA \\
\hline & $\mathrm{R}$ & AACCCATGAAGCGATGGTAG \\
\hline \multirow[t]{3}{*}{ FGF21 } & $\mathrm{F}$ & GCCAACAACCAGATGGAACTC \\
\hline & $\mathrm{R}$ & CTGGTACACATTGTATCCGTC \\
\hline & & CTT \\
\hline \multirow[t]{3}{*}{ GDNF } & $\mathrm{F}$ & CAAAAGACTGAAAAGGTCACC \\
\hline & & AGAT \\
\hline & $\mathrm{R}$ & GCTTGCCGGTTCCTCTCTCT \\
\hline \multirow[t]{2}{*}{ IL-15 } & $\mathrm{F}$ & СTTCTTAACTGAGGCTGG \\
\hline & $\mathrm{R}$ & GCAACTGGGATGAAAGTC \\
\hline \multirow[t]{2}{*}{ LTBP2 } & $\mathrm{F}$ & AAGAACACTGCGCTCCTCAT \\
\hline & $\mathrm{R}$ & TGGAAGCCAGTCTCACACAG \\
\hline \multirow[t]{2}{*}{ Decorin } & $\mathrm{F}$ & TCGGATACATCCGCATCTCAGA \\
\hline & $\mathrm{R}$ & GGCACTCTGAGGAGTTTGTTGT \\
\hline \multirow[t]{2}{*}{ CHI3L1 } & $\mathrm{F}$ & GGGCAGTGGATTTGGATG \\
\hline & $\mathrm{R}$ & TGCAAGTGACCAGACTCCTG \\
\hline \multirow[t]{2}{*}{ Irisin } & $\mathrm{F}$ & GACCTGGAGGAGGACACAGA \\
\hline & $\mathrm{R}$ & CСCATCTCCTTCATGGTCAC \\
\hline \multirow[t]{2}{*}{ SERP4 } & $\mathrm{F}$ & CGCAGGATGAGTCAAGTCAG \\
\hline & $\mathrm{R}$ & TGACCAGATGTCCACAAGGA \\
\hline \multirow[t]{2}{*}{ Metrn 1} & $\mathrm{~F}$ & TCGAGGATGTCACCCATGTA \\
\hline & $\mathrm{R}$ & CCCTGGTCGTACTCCACACT \\
\hline \multirow[t]{2}{*}{ HO-1 } & $\mathrm{F}$ & CGACAGCATGTCCCAGGATT \\
\hline & $\mathrm{R}$ & TCGCTCTATCTCСТCTTCCAGG \\
\hline SOD2 & $\mathrm{F}$ & GGCCAAGGGAGATGTTACAA \\
\hline & $\mathrm{R}$ & GCTTGATAGCCTCCAGCAAC \\
\hline GPX1 & $\mathrm{F}$ & GCTGCTCATTGAGAATGTCG \\
\hline & $\mathrm{R}$ & GAATCTCTTCATTCTTGCCATT \\
\hline Nrf2 & $\mathrm{F}$ & CAAGAGCAACAGATGAATGAG \\
\hline & $\mathrm{R}$ & ACTTTAATCGTAGTCGGTGTAG \\
\hline GST & $\mathrm{F}$ & CCCTGAGAACCAGAGTCAGC \\
\hline & $\mathrm{R}$ & CTGCGGATTCCCTACACATT \\
\hline
\end{tabular}


Table I. Continued.

\begin{tabular}{|c|c|c|}
\hline Gene & Direction & Sequence $\left(5^{\prime}-3^{\prime}\right)$ \\
\hline \multirow[t]{2}{*}{ Catalase } & $\mathrm{F}$ & GAGGTCACCCACGATATTACCAGA \\
\hline & $\mathrm{R}$ & AGAATTTCACTGCAAACCCACG \\
\hline \multirow[t]{2}{*}{ Keap1 } & $\mathrm{F}$ & GTGCATCGACTGGGTCAAATAC \\
\hline & $\mathrm{R}$ & CTGGAAGATCTGCACCAGGTAG \\
\hline \multirow[t]{2}{*}{ Nrf1 } & $\mathrm{F}$ & TTACTCTGCTGTGGCTGATGG \\
\hline & $\mathrm{R}$ & CCTCTGATGCTTGCGTCGTCT \\
\hline \multirow[t]{2}{*}{ PGC1a } & $\mathrm{F}$ & CCTTTCTGAACTTGATGTGA \\
\hline & $\mathrm{R}$ & ATGCTCTTTGCTTTATTGCT \\
\hline \multirow[t]{2}{*}{ Imp-11 } & $\mathrm{F}$ & AGACGAAGAACCACCCACAG \\
\hline & $\mathrm{R}$ & GTCTCCATGAGGGACTGGAA \\
\hline \multirow[t]{2}{*}{$\operatorname{Tr} x 2$} & $\mathrm{~F}$ & CAGTTATGTGGCCCTGGAGT \\
\hline & $\mathrm{R}$ & TCGGGAGTTTTCTGATGAGG \\
\hline \multirow{2}{*}{ Nqo1 } & $\mathrm{F}$ & TCCGCCCCCAACTTCTG \\
\hline & $\mathrm{R}$ & TCTGCGTGGGCCAATACA \\
\hline \multirow{2}{*}{ UBE2E3 } & $\mathrm{F}$ & GGGAGTCATCTGCCTGGATA \\
\hline & $\mathrm{R}$ & TCCTGTCGTGTTCTGCTCTG \\
\hline \multirow{2}{*}{ GCLC } & $\mathrm{F}$ & СTCTGCCTATGTGGTATTTG \\
\hline & $\mathrm{R}$ & TTGCTTGTAGTCAGGATGG \\
\hline \multirow[t]{2}{*}{ Myogenin } & $\mathrm{F}$ & GACCCTACAGGTGCCCACAA \\
\hline & $\mathrm{R}$ & АCATATCCTCCACCGTGATGCT \\
\hline \multirow[t]{2}{*}{ MuRF1 } & $\mathrm{F}$ & GTGAAGTTGCCCCCTTACAA \\
\hline & $\mathrm{R}$ & TGGAGATGCAATTGCTCAGT \\
\hline \multirow[t]{2}{*}{ Myf-6 } & $\mathrm{F}$ & CCGGGAGCGACAGCAGTGG \\
\hline & $\mathrm{R}$ & AGCCGGTGCAGCAGGTCCT \\
\hline \multirow[t]{2}{*}{ MyoD1 } & $\mathrm{F}$ & GCGACAAGCCGATGACTTCTAT \\
\hline & $\mathrm{R}$ & GGTCCAGGTCCTCAAAAAAGC \\
\hline \multirow[t]{2}{*}{ Myf-5 } & $\mathrm{F}$ & GAGCCAAGAGTAGCAGCCTTCG \\
\hline & $\mathrm{R}$ & GTTCTTTCGGGACCAGACAGGG \\
\hline \multirow[t]{2}{*}{ Atrogin-1 } & $\mathrm{F}$ & CCTTCTCCAGGCCAGTAGGTG \\
\hline & $\mathrm{R}$ & CGCGTCCGCGCTCTGTA \\
\hline \multirow[t]{2}{*}{ RPB3 } & $\mathrm{F}$ & CGATCCAGACAACGCACTTA \\
\hline & $\mathrm{R}$ & AGACAGGGCTGAGAGGACAA \\
\hline \multirow[t]{2}{*}{ Sp1 } & $\mathrm{F}$ & TGAATGCTGCTCAACTGTCC \\
\hline & $\mathrm{R}$ & CTCCACCTGCTGTCTCATCA \\
\hline \multirow[t]{2}{*}{ HSP60 } & $\mathrm{F}$ & AAATCCGGAGAGGTGTGATG \\
\hline & $\mathrm{R}$ & CTTCAGGGGTTGTCACAGGT \\
\hline \multirow[t]{2}{*}{ HSP70 } & $\mathrm{F}$ & GTTGCATGTTCTTTGCGTTT \\
\hline & $\mathrm{R}$ & TACACAGGGTGGCAGTGCT \\
\hline \multirow[t]{2}{*}{ HSP90 } & $\mathrm{F}$ & GGTGTCGGCTTCTACTCTGC \\
\hline & $\mathrm{R}$ & CTGCTCATCATCGTTGTGCT \\
\hline \multirow[t]{2}{*}{ HSP27 } & $\mathrm{F}$ & CCTGGTGTCCTCTTCCCTGT \\
\hline & $\mathrm{R}$ & TGGTGATCTCCGCTGATTGTG \\
\hline \multirow[t]{2}{*}{ Nrxn2 } & $\mathrm{F}$ & TCAACCTGTCCCTCAAGTCC \\
\hline & $\mathrm{R}$ & GGTGTAATCCTCCTGCGTGT \\
\hline \multirow[t]{2}{*}{ Ntn4 } & $\mathrm{F}$ & GGCCTGGAAGATGATGTTGT \\
\hline & $\mathrm{R}$ & TCTCTGACAAGGGCAGGACT \\
\hline
\end{tabular}

A number of genes listed in this table are not mentioned in the text, this is primarily because the discussion focused on the genes of interest with regard to the present study. IL, interleukin; F, forward; $\mathrm{R}$, reverse; SPARC, secreted protein acidic and rich in cysteine; GDF, growth differentiation factor; LIF, leukemia inhibitory factor; RARRES1, retinoic acid receptor responder (tazarotene induced) 1; OSM, oncostatin M; FGF, fibroblast growth factor; GDNF, glial cell derived neurotrophic factor; LTBP2, latent-transforming growth factor
Table I. Continued.

beta-binding protein 2; CHI311, chitinase-3-like protein 1; SERP4, septin 4; Metrn, meteorin; HO, heme oxygenase; SOD, superoxide dismutase; GPX, glutathione peroxidase; Nrf, nuclear respiratory factor; GST, glutathione S-transferase; Keap1; kelch-like ECH associated protein 1; PGC1a, peroxisome proliferator-activated receptor gamma coactivator 1 alpha; Imp-11, importin 11; Trx2, thioredoxin reductase-2; Nqo1, NADPH quinone oxidoreductase 1; UBE2E3, ubiquitin-conjugation enzyme E2 E3; GCLC, glutamate-cysteine ligase catalytic subunit; MuRf1, muscle ring-finger protein-1; Myf, myogenic factor; MyoD1, myogenic differentiation 1; RPB3, RNA polymerase B3; Sp1, specificity protein; HSP, heat shock protein; Nrxn, neurexin; Ntn, netrin.

Table II. Food intake, final body weight, and gastrocnemius weight.

\begin{tabular}{llll}
\hline Variable & $\begin{array}{l}1 \mathrm{mg} / \mathrm{kg} \\
\mathrm{PN} \mathrm{HCl}\end{array}$ & $\begin{array}{l}7 \mathrm{mg} / \mathrm{kg} \\
\mathrm{PN} \mathrm{HCl}\end{array}$ & $\begin{array}{r}35 \mathrm{mg} / \mathrm{kg} \\
\mathrm{PN} \mathrm{HCl}\end{array}$ \\
\hline $\begin{array}{l}\text { Food intake } \\
(\mathrm{g} / 6 \mathrm{wk})\end{array}$ & $731 \pm 10$ & $787 \pm 15$ & $772 \pm 24$ \\
$\begin{array}{l}\text { Final body wt (g) } \\
\text { Gastrocnemious }\end{array}$ & $412 \pm 9$ & $444 \pm 9$ & $437 \pm 13$ \\
$\begin{array}{l}\text { muscle (g) } \\
\text { PLP in gastrocnemius } \\
\text { muscle (nmol/g) }\end{array}$ & $2.4 \pm 0.1$ & $2.6 \pm 0.1$ & $2.7 \pm 0.1$ \\
\hline
\end{tabular}

Values are presented as the mean \pm standard error of the mean. $n=8$, ${ }^{\text {a }} \mathrm{P}<0.05$ vs. $1 \mathrm{mg} / \mathrm{kg}$ group. PLP, pyridoxal 5'-phosphate; PM, pyridoxine.

The effect of dietary vitamin B6 on the expression of genes associated with myogenesis and sarcopenia was also evaluated. Among the 8 genes analysed, only myogenin expression was significantly affected by dietary vitamin B6. Compared with the $1 \mathrm{mg} / \mathrm{kg} \mathrm{PN} \mathrm{HCl}$ group, there was a $52 \%$ elevation in myogenin expression in the $7 \mathrm{mg} / \mathrm{kg}$ PN HCl. Group (Table V; $\mathrm{P}<0.05$ ); however, there was no significant difference between the 1 and $35 \mathrm{mg} / \mathrm{kg}$ PN HCl groups (Table V).

Of the 4 HSP genes evaluated, a significant increase was observed in the gene expression of HSP60 in the $7 \mathrm{mg} / \mathrm{kg}$ PN $\mathrm{HCl}$ group compared with the $1 \mathrm{mg} / \mathrm{kg} \mathrm{PN} \mathrm{HCl}$ group (+66\%; $\mathrm{P}<0.05$; Table VI). However, no significant differences were observed between levels of HSP70, HSP90 or HSP27 among any of the groups (Table VI). Furthermore, there was no significant difference in HSP60 expression between the 1 and $35 \mathrm{mg} / \mathrm{kg} \mathrm{PN} \mathrm{HCl}$ groups.

The results of the microarray demonstrated that the expressions of neurexin (Nrxn)2 and netrin (Ntn)4 were also altered by dietary supplemental vitamin B6 (data not shown). RT-qPCR results showed that the $7 \mathrm{mg} / \mathrm{kg} \mathrm{PN} \mathrm{HCl}$ diet elevated the expression of Nrxn2 and Ntn4 by 85 and $82 \%$, respectively (Table VII; P<0.05) compared with the $1 \mathrm{mg} / \mathrm{kg}$ $\mathrm{PN} \mathrm{HCl}$ diet. No significant differences were observed in Nrxn 2 or Ntn 4 levels between the 1 and $35 \mathrm{mg} / \mathrm{kg}$ PN HCl groups. 


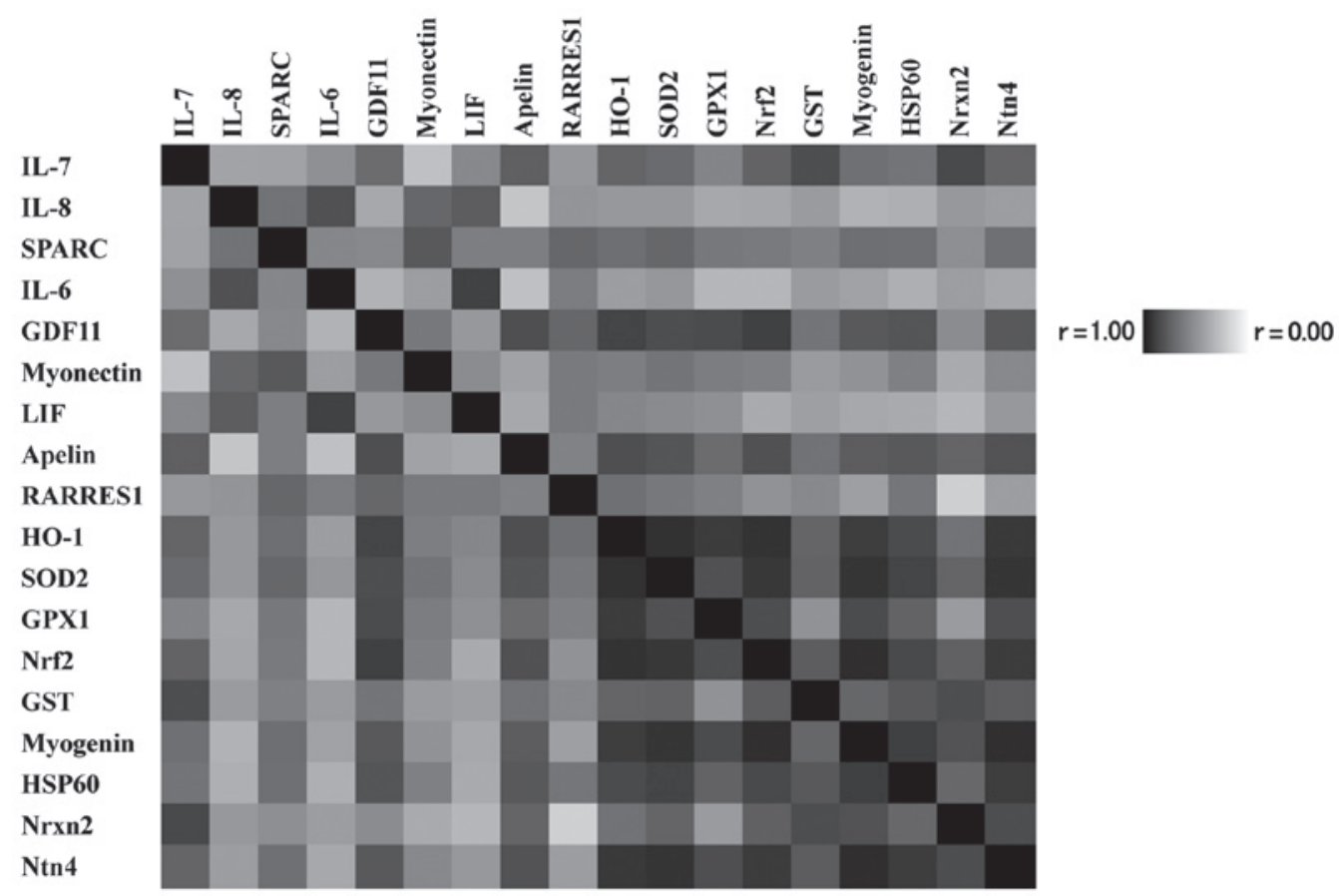

Figure 1. Correlation matrix among the gene expressions altered by dietary level of vitamin B6. The dark colour scheme corresponds to correlation strength as shown by the deep colour bar. IL, interleukin; SPARC, secreted protein acidic and rich in cysteine; GDF, growth differentiation factor; LIF, leukemia inhibitory factor; RARRES1, retinoic acid receptor responder (tazarotene induced) 1; HO, heme oxygenase; SOD, superoxide dismutase; GPX, glutathione peroxidase; Nrf, nuclear respiratory factor; GST, glutathione S-transferase; HSP, heat shock protein; Nrxn, neurexin; Ntn, netrin.

In the present study, it was investigated whether there was any correlation between the genes that were affected by the dietary levels of vitamin B6. Significant correlations were observed between the expression of Nrf2 and the following genes (all of which were significantly affected by dietary vitamin B6): IL-7, SPARC, GDF11, myonectin, apelin, RARRES1, HO-1, SOD2, GPX1, GST, myogenin, HSP60, Nrxn2 and Ntn4 $(\mathrm{P}<0.05$; Fig. 1). Furthermore, HSP60 expression was found to be significantly correlated with the expressions of IL-7, SPARC, GDF11, myonectin, apelin, RARRES1, HO-1, SOD2, GPX1, Nrf2, GST, myogenin, HSP60, Nrxn2 and Ntn4 (P<0.05; Fig. 1). Myogenin expression was demonstrated to be significantly correlated with IL-7, SPARC, GDF11, myonectin, apelin, HO-1, SOD2, GPX1, GST, myogenin, HSP60, Nrxn2 and Ntn4 expressions $(\mathrm{P}<0.05$; Fig. 1).

\section{Discussion}

To the best of our knowledge, the present study is the first to evaluate the effect of dietary vitamin B6 level on the expression of genes in the gastrocnemius muscle of rats. The results indicated that the recommended levels of dietary vitamin B6 $(7 \mathrm{mg} / \mathrm{kg} \mathrm{PN} \mathrm{HCl})$ significantly elevated the mRNA of several myokines, such as IL-7, IL-8, SPARC, IL-6, GDF11, myonectin, LIF, apelin and RARRES1, compared with a low vitamin B6 diet (1 mg/kg PN HCl; marginal vitamin B6 deficiency level). Compared with the $1 \mathrm{mg} / \mathrm{kg}$ group, the $7 \mathrm{mg} / \mathrm{kg} \mathrm{PN} \mathrm{HCl}$ group also exhibited higher expressions of antioxidant genes, such as HO-1, SOD2, GPX1 and GST, and their master transcription factor, Nrf2. Furthermore, compared with the low vitamin B6 diet, the recommended level of dietary vitamin B6 increased the expression of myogenin, which is essential for the development of functional skeletal muscle, and HSP60, a mitochondrial protein which is a key factor in muscle cytoprotection (24). Similar results were observed in the expressions of Nxrn2, a membrane protein important for motor neuron neurotransmitters, and Ntn4, a secreted molecule involved in angiogenesis. Notably, in the majority of genes that were affected by the dietary level of vitamin B6, there were no significant differences in gene expressions between the 1 and $35 \mathrm{mg} / \mathrm{kg} \mathrm{PN} \mathrm{HCl}$ groups, whereas there was a significant difference in the levels of PLP between the two groups. These results suggest that the recommended level of vitamin $\mathrm{B} 6(7 \mathrm{mg} / \mathrm{kg} \mathrm{PN} \mathrm{HCl})$ may be important for the expression of genes that are beneficial for skeletal muscles, whereas excessive levels of vitamin B6 (35 mg $\mathrm{PN} \mathrm{HCl} / \mathrm{kg}$ ) may not facilitate this expression.

In the present study, it is notable that almost all of the genes whose expressions were elevated by the recommended level of dietary vitamin B6 were exercise-induced genes. Myokines are released during muscle contraction (7) and may be partly responsible for the beneficial effects of exercise on the reduction of risk for chronic diseases including diabetes, cardiovascular disease and cancers $(7-9,25,26)$. A previous study reported that exercise upregulated both antioxidant enzymes and the antioxidant defence system that is associated with Nrf2 (27). Exercise induces the expression of myogenin in human skeletal muscle (28), and HSP60 is upregulated in cardiac and skeletal muscles following endurance training (29). Furthermore, Nxrn2 may be associated with motor neuron function, as the knockdown of Nrxn2 results in a significant decrease in motor axon excitability (30). Ntn4 is a putative angiogenic factor, and exercise has previously been demonstrated to induce angiogenesis (31). Further 
Table III. Effect of dietary level of vitamin B6 on expression of myokine genes in gastrocnemius muscle of rats.

\begin{tabular}{llcc}
\hline & \multicolumn{3}{c}{ Relative gene expression } \\
\cline { 2 - 4 } Gene & $1 \mathrm{mg} / \mathrm{kg}$ & $7 \mathrm{mg} / \mathrm{kg}$ & $35 \mathrm{mg} / \mathrm{kg}$ \\
& PN HCl & PN HCl & PN HCl \\
\hline IL-7 & $1.00 \pm 0.09$ & $2.07 \pm 0.28^{\mathrm{b}}$ & $1.33 \pm 0.16^{\mathrm{c}}$ \\
IL-8 & $1.00 \pm 0.04^{\mathrm{a}}$ & $2.05 \pm 0.28^{\mathrm{b}}$ & $1.61 \pm 0.16$ \\
SPARC & $1.00 \pm 0.11$ & $1.92 \pm 0.20^{\mathrm{b}}$ & $1.39 \pm 0.07^{\mathrm{c}, \mathrm{d}}$ \\
IL-6 & $1.00 \pm 0.10$ & $1.77 \pm 0.22^{\mathrm{b}}$ & $1.32 \pm 0.20$ \\
GDF11 & $1.00 \pm 0.04$ & $1.75 \pm 0.15^{\mathrm{b}}$ & $1.56 \pm 0.18^{\mathrm{b}}$ \\
Myonectin & $1.00 \pm 0.08$ & $1.65 \pm 0.18^{\mathrm{b}}$ & $1.46 \pm 0.13^{\mathrm{b}}$ \\
LIF & $1.00 \pm 0.09$ & $1.62 \pm 0.13^{\mathrm{b}}$ & $1.23 \pm 0.03$ \\
Apelin & $1.00 \pm 0.09$ & $1.61 \pm 0.17^{\mathrm{b}}$ & $1.33 \pm 0.11$ \\
RARRES1 & $1.00 \pm 0.11$ & $1.53 \pm 0.10^{\mathrm{b}}$ & $1.33 \pm 0.08$ \\
OSM & $1.00 \pm 0.12$ & $1.66 \pm 0.33$ & $1.07 \pm 0.16$ \\
FGF21 & $1.00 \pm 0.13$ & $1.54 \pm 0.27$ & $1.16 \pm 0.17$ \\
GDNF & $1.00 \pm 0.10$ & $1.53 \pm 0.24$ & $1.18 \pm 0.18$ \\
IL-15 & $1.00 \pm 0.07$ & $1.22 \pm 0.15$ & $1.30 \pm 0.20$ \\
LTBP2 & $1.00 \pm 0.11$ & $1.19 \pm 0.10$ & $0.89 \pm 0.08$ \\
Decorin & $1.00 \pm 0.07$ & $1.17 \pm 0.09$ & $1.02 \pm 0.04$ \\
CHI3L1 & $1.00 \pm 0.09$ & $1.14 \pm 0.10$ & $0.94 \pm 0.08$ \\
Irisin & $1.00 \pm 0.10$ & $1.10 \pm 0.11$ & $0.94 \pm 0.08$ \\
SERP4 & $1.00 \pm 0.11$ & $1.02 \pm 0.09$ & $0.91 \pm 0.08$ \\
Metrn1 & $1.00 \pm 0.10$ & $1.00 \pm 0.06$ & $0.96 \pm 0.07$ \\
\hline
\end{tabular}

Values are presented as the mean \pm standard error of the mean. $\mathrm{n}=6-8$. ${ }^{\mathrm{a}}$ Indicate studies using 6 animals and others are the data of 8 animals. ${ }^{\mathrm{b}} \mathrm{P}<0.05 \mathrm{vs} .1 \mathrm{mg} / \mathrm{kg}$ group, ${ }^{\mathrm{c}} \mathrm{P}<0.05 \mathrm{vs} .7 \mathrm{mg} / \mathrm{kg}$ group. ${ }^{\mathrm{d}}$ Indicate studies using 7 animals and others are the data of 8 animals. PN, pyridoxine; IL, interleukin; SPARC, secreted protein acidic and rich in cysteine; GDF, growth differentiation factor; LIF, leukemia inhibitory factor; RARRES1, retinoic acid receptor responder (tazarotene induced) 1; OSM, oncostatin M; FGF, fibroblast growth factor; GDNF, glial cell derived neurotrophic factor; LTBP2, latent-transforming growth factor beta-binding protein 2; CHI3L1, chitinase-3-like protein 1; SERP4, septin 4; Metrn, meteorin.

investigation is required to determine whether the beneficial effects of dietary vitamin B6 in skeletal muscle are due to the altered expression of factors similar to that observed during physical exercise.

The expressions of HO-1, SOD2, GPX1 and GST (antioxidant genes that are also Nrf2-regulated factors) were increased in the $7 \mathrm{mg} / \mathrm{kg} \mathrm{PN} \mathrm{HCl}$ group compared with the $1 \mathrm{mg} / \mathrm{kg} \mathrm{PN} \mathrm{HCl}$ group. It has previously been reported that vitamin B6 may have antioxidant functions in the body (32), and it is therefore important to investigate the possibility that the antioxidant function of vitamin B6 may occur in part via the modulation of the Nrf2 signalling pathway. The results of the present study suggested a possible physiological role of vitamin B6 as a regulator of the Nrf2 signalling pathway. However, further investigations are necessary to investigate this possibility.

It has been reported that myokines may possess some anti-disease functions. RARRES1 may serve a role in the
Table IV. Effect of dietary level of vitamin B6 on expression of genes related to mitochondrial function and $\mathrm{Nrf} 2$ in gastrocnemius muscle of rats.

\begin{tabular}{llcc}
\hline & \multicolumn{3}{c}{ Relative gene expression } \\
\cline { 2 - 4 } Gene & $1 \mathrm{mg} / \mathrm{kg}$ & $7 \mathrm{mg} / \mathrm{kg}$ & $35 \mathrm{mg} / \mathrm{kg}$ \\
\hline HO-1 & $1.00 \pm 0.05^{\mathrm{a}}$ & $1.71 \pm 0.24^{\mathrm{b}}$ & $1.18 \pm 0.13$ \\
SOD2 & $1.00 \pm 0.06$ & $1.56 \pm 0.17^{\mathrm{b}}$ & $1.18 \pm 0.14$ \\
GPX1 & $1.00 \pm 0.12$ & $1.56 \pm 0.20^{\mathrm{b}}$ & $0.96 \pm 0.14$ \\
Nrf2 & $1.00 \pm 0.06$ & $1.45 \pm 0.11^{\mathrm{b}}$ & $1.19 \pm 0.14$ \\
GST & $1.00 \pm 0.06$ & $1.28 \pm 0.07^{\mathrm{b}}$ & $1.09 \pm 0.06^{\mathrm{a}}$ \\
Catalase & $1.00 \pm 0.05$ & $1.45 \pm 0.18$ & $1.17 \pm 0.18^{\mathrm{a}}$ \\
Keap1 & $1.00 \pm 0.03$ & $1.42 \pm 0.13$ & $1.23 \pm 0.15$ \\
Nrf1 & $1.00 \pm 0.06$ & $1.38 \pm 0.19$ & $1.09 \pm 0.19$ \\
PGC1a & $1.00 \pm 0.05$ & $1.12 \pm 0.11$ & $0.97 \pm 0.04$ \\
Imp-11 & $1.00 \pm 0.06$ & $1.10 \pm 0.01$ & $1.05 \pm 0.06$ \\
Trx & $1.00 \pm 0.09$ & $1.10 \pm 0.09$ & $1.04 \pm 0.05$ \\
Nqo1 & $1.00 \pm 0.10^{\mathrm{a}}$ & $1.07 \pm 0.12$ & $0.85 \pm 0.07$ \\
UBE2E3 & $1.00 \pm 0.09$ & $1.03 \pm 0.04$ & $1.10 \pm 0.12$ \\
GCLC & $1.00 \pm 0.09^{\mathrm{a}}$ & $1.03 \pm 0.07$ & $0.90 \pm 0.04^{\mathrm{a}}$ \\
\hline
\end{tabular}

Values are presented as the mean \pm standard error of the mean. $\mathrm{n}=7-8$; andicates studies using 7 animals and others are the data of 8 animals. ${ }^{\mathrm{b}} \mathrm{P}<0.05 \mathrm{vs} .1 \mathrm{mg} / \mathrm{kg}$ group. Nrf, nuclear respiratory factor; PN, pyridoxine; HO, heme oxygenase; SOD, superoxide dismutase; GPX, glutathione peroxidase; GST, glutathione S-transferase; Keap1; kelch-like ECH associated protein 1; Nrf1, nuclear respiratory factor 1; PGC1a, peroxisome proliferator-activated receptor gamma coactivator 1 alpha; Imp-11, importin 11; Trx, thioredoxin reductase; Nqo1, NADPH quinone oxidoreductase 1; UBE2E3, ubiquitin-conjugation enzyme E2 E3; GCLC, glutamate-cysteine ligase catalytic subunit.

Table V. Effect of dietary level of vitamin B6 on expression of genes related to myogenesis and sarcopenia in gastrocnemius muscle of rats.

\begin{tabular}{lccc}
\hline & \multicolumn{3}{c}{ Relative gene expression } \\
\cline { 2 - 4 } Gene & $1 \mathrm{mg} / \mathrm{kg}$ & $7 \mathrm{mg} / \mathrm{kg}$ & $35 \mathrm{mg} / \mathrm{kg}$ \\
$\mathrm{PN} \mathrm{HCl}$ & $\mathrm{PN} \mathrm{HCl}$ & $\mathrm{PN} \mathrm{HCl}$ \\
\hline Myogenin & $1.00 \pm 0.06$ & $1.52 \pm 0.20^{\mathrm{a}}$ & $0.82 \pm 0.05^{\mathrm{b}}$ \\
MuRF1 & $1.00 \pm 0.07$ & $1.35 \pm 0.17$ & $1.21 \pm 0.16$ \\
Myf-6 & $1.00 \pm 0.09$ & $1.33 \pm 0.32$ & $1.06 \pm 0.33$ \\
MyoD1 & $1.00 \pm 0.12$ & $1.27 \pm 0.18$ & $1.09 \pm 0.19$ \\
Myf-5 & $1.00 \pm 0.01$ & $1.24 \pm 0.11$ & $1.06 \pm 0.06$ \\
Atrogin-1 & $1.00 \pm 0.15$ & $1.24 \pm 0.18$ & $1.46 \pm 0.10$ \\
RPB3 & $1.00 \pm 0.06$ & $1.08 \pm 0.03$ & $0.95 \pm 0.02$ \\
Sp1 & $1.00 \pm 0.10$ & $1.08 \pm 0.06$ & $0.93 \pm 0.07$ \\
\hline
\end{tabular}

Values are presented as the mean \pm standard error of the mean. $n=6$ or 8 .

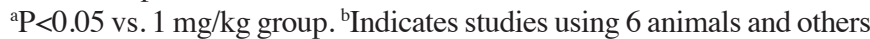
are the data of 8 animals. PN, pyridoxine; MuRF1, muscle ring-finger protein-1; Myf, myogenic factor; MyoD1, myogenic differentiation 1; RPB3, RNA polymerase B3; Sp1, specificity protein. 
Table VI. Effect of dietary level of vitamin B6 on gene expression of HSPs in gastrocnemius muscle of rats.

\begin{tabular}{llcc}
\hline & \multicolumn{3}{c}{ Relative gene expression } \\
\cline { 2 - 4 } Gene & $\begin{array}{l}1 \mathrm{mg} / \mathrm{kg} \\
\mathrm{PN} \mathrm{HCl}\end{array}$ & $\begin{array}{l}7 \mathrm{mg} / \mathrm{kg} \\
\mathrm{PNCl}\end{array}$ & $\begin{array}{c}35 \mathrm{mg} / \mathrm{kg} \\
\mathrm{PN} \mathrm{HCl}\end{array}$ \\
\hline HSP60 & $1.00 \pm 0.09$ & $1.66 \pm 0.19^{\mathrm{b}}$ & $1.20 \pm 0.11$ \\
HSP70 & $1.00 \pm 0.07^{\mathrm{a}}$ & $2.00 \pm 0.48$ & $1.23 \pm 0.28^{\mathrm{a}}$ \\
HSP90 & $1.00 \pm 0.07$ & $1.43 \pm 0.22$ & $1.37 \pm 0.21$ \\
HSP27 & $1.00 \pm 0.07$ & $1.07 \pm 0.11$ & $0.83 \pm 0.16$
\end{tabular}

Values are presented as the mean \pm standard error of the mean. $n=7-8$; aindicates studies using 7 animals and others are the data of 8 animals. ${ }^{\mathrm{b}} \mathrm{P}<0.05 \mathrm{vs} .1 \mathrm{mg} / \mathrm{kg}$ group, HSP, heat shock protein; $\mathrm{PN}$, pyridoxine.

Table VII. Effect of dietary level of vitamin B6 on gene expression of Nrxn2 and Ntn4 in gastrocnemius muscle of rats.

Relative gene expression

\begin{tabular}{lccc}
\cline { 2 - 4 } Gene & $1 \mathrm{mg} / \mathrm{kg}$ & $7 \mathrm{mg} / \mathrm{kg}$ & $35 \mathrm{mg} / \mathrm{kg}$ \\
& PN HCl & PN HCl & PNCl \\
\hline Nrxn2 & $1.00 \pm 0.08$ & $1.85 \pm 0.23^{\mathrm{a}}$ & $1.02 \pm 0.09^{\mathrm{b}, c}$ \\
Ntn4 & $1.00 \pm 0.08$ & $1.82 \pm 0.24^{\mathrm{a}}$ & $1.14 \pm 0.18^{\mathrm{c}}$
\end{tabular}

Values are presented as the mean \pm standard error of the mean. $n=7-8$. ${ }^{\mathrm{a}} \mathrm{P}<0.05$ vs. $1 \mathrm{mg} / \mathrm{kg}$ group. ${ }^{\mathrm{b}}$ Indicates studies using 7 animals and others are the data of 8 animals. ${ }^{c} \mathrm{P}<0.05 \mathrm{vs} .7 \mathrm{mg} / \mathrm{kg}$ group. Nrxn, neurexin; Ntn, netrin; PN, pyridoxine.

pathogenesis of colorectal adenocarcinoma, as it has been reported that the downregulation of RARRES1 is associated with disease progression (33). Another study reported that tumour growth in the colon was increased in SPARC-null mice, suggesting that SPARC may possess anti-tumour properties (34). A previous study by the present authors indicated that supplementing a low vitamin B6 diet with dietary vitamin B6 lowered colon tumorigenesis in mice (35). In the present study, the expressions of both RARRES1 and SPARC were increased by dietary supplemental vitamin B6 $(7 \mathrm{mg} / \mathrm{kg}$ PN HC) added to a low vitamin B6 diet. However, further investigations are necessary to examine the involvement of these myokines and the underlying mechanisms responsible for the anti-tumour effects of dietary vitamin B6.

In the present study, correlations among the gene expressions affected by dietary vitamin B6 were also investigated. Although Nrf2 has previously been reported as a potent activator of IL-6 gene transcription in vivo (36), the results of the present study did not find any significant correlation between Nrf2 and IL-6. Intriguingly, IL-7, SPARC, GDF11, myonectin, apelin and RARRESS1 expressions were positively correlated with Nrf2. It is therefore necessary to investigate whether the alterations in myokine expressions induced by dietary vitamin B6 is associated with altered
Nrf2 expression. As myogenin is the major regulator of muscle regeneration, the correlation of gene expressions between myokines and myogenin was also evaluated. The results demonstrated that the expression of myogenin was significantly correlated with the expression of IL-7, SPARC, GDF11, myonectin and apelin. Furthermore a significant correlation was found between HSP60 and IL-7, SPARC, GDF11, myonectin, apelin and RARRES1. Further study is required to evaluate the effects of Nrf2, HSP60 and myogenin on the expressions of other myokines in muscle cell cultures.

In conclusion, the present study demonstrated that the recommended level of dietary vitamin B6 elevated the expression of several myokine genes, Nrf2-regulated genes, myogenin, HSP60, Nrxn2 and Ntn4 compared with a low vitamin B6 diet. However, excessive levels of dietary vitamin B6 did not induce the same response as $7 \mathrm{mg} / \mathrm{kg} \mathrm{PN} \mathrm{HCl}$. This suggests that the recommended level of dietary vitamin B6 is critical for the expression of these genes in the gastrocnemius muscle of rats, and these factors may be beneficial for muscle health. Notably, the elevations in gene expression induced by supplemental vitamin B6 were similar to responses to exercise. Accordingly, the findings of the present study provide a novel insight into the physiological role of vitamin B6 in skeletal muscles as an exercise-like factor. Further study is required to fully understand the role of vitamin B6 in skeletal muscles.

\section{Acknowledgements}

The present study was supported in part by the Grant of Vitamin B Research Committee of The Vitamin Society of Japan.

\section{References}

1. Ink SL and Henderson LM: Vitamin B6 metabolism. Ann Rev Nutr 4: 455-470, 1984.

2. Manore MM: Vitamin B6 and exercise. Int J Sport Nutr 4: 89-103, 1994.

3. Okada M, Ishikawa K and Watanabe K: Effect of vitamin B6 deficiency on glycogen metabolism in the skeletal muscle, heart, and liver of rats. J Nutr Sci Vitaminol (Tokyo) 37: 349-357, 1997.

4. Black AL, Guirard BM and Snell EE: Increased muscle phosphorylase in rats fed high levels of vitamin B6. J Nutr 107: 1962-1968, 1977.

5. Izumi R, Suzuki N, Kato K, Warita H, Tateyama M, Nakashima I and Itoyama Y: A case of McArdle disease: Efficacy of vitamin B6 on fatigability and impaired glycogenolysis. Intern Med 49: 1623-1625, 2010.

6. Crozier PG, Cordain L and Sampson DA: Exercise-induced changes in plasma vitamin B-6 concentrations do not vary with exercise intensity. Am J Clin Nutr 60: 552-558, 1994.

7. Raschke $\mathrm{S}$ and Eckel J: Adipo-myokines: Two sides of the same coin-mediators of inflammation and mediators of exercise. Mediators Inflamm 2013: 320724, 2013.

8. Yoon JH, Kim J, Song P, Lee TG, Suh PG and Ryu SH: Secretomics for skeletal muscle cells: A discovery of novel regulators? Adv Biol Regul 52: 340-350, 2012.

9. Pedersen BK and Febbraio MA: Muscles, exercise and obesity: Skeletal muscle as a secretory organ. Nat Rev Endocrinol 8: 457-465, 2012.

10. Pedersen BK: Muscles and their myokines. J Exp Biol 214: 337-346, 2011.

11. Ellingsgaard H, Hauselmann I, Schuler B, Habib AM, Baggio LL, Meier DT, Eppler E, Bouzakri K, Wueest S, Muller YD, et al: Interleukin-enhances insulin secretion by increasing glucagon-like peptide-secretion from cells and alpha cells. Nat Med 17: 1481-1489, 2011. 
12. Pedersen BK and Febbraio MA: Muscle as an endocrine organ: Focus on muscle-derived interleukin-6. Physiol Rev 88: 1379-1406, 2008.

13. Wakabayashi N, Slocum SL, Skoko JJ, Shin S and Kensler TW: When NRF2 talks, who's listening? Antioxid Redox Signal 13: $1649-1663,2010$

14. Muthusamy VR, Kannan S, Sadhaasivam K, Gounder SS, Davidson CJ, Boeheme C, Hoidal JR, Wang L and Rajasekaran NS: Acute exersice stress activates Ntf2/ARE signaling and promotes antioxidant mechanisms in the myocardium. Free Radic Biol Med 52: 366-376, 2012.

15. Wang P, Li CG, Qi Z, Cui D and Ding S: Acute exercise stress promotes Ref1/Nrf2 signalling and increases mitochondrial antioxidant activity in skeletal muscle. Exp Physiol 101: 410-420, 2016

16. Al-Sawaf O, Fragoulis A, Rosen C, Keimes N, Liehn EA, Hölzle F, Kan YW, Pufe T, Sönmez TT and Wruck CJ: Nrf2 augments skeletal muscle regeneration after ischaemia-reperfusion injury. J Pathol 234: 538-547, 2014.

17. Bayer ML, Paulsen G, Ugelstad I, Hallen J and Raastad T: The role of Heat Shock Proteins in cytoprotection of skeletal muscle. FASEB J 22: 1165, 2008

18. Salo DC, Donovan CM and Davies KJ: HSP70 and other possible heat shock or oxidative stress proteins are induced in skeletal muscle, heart, and liver during exercise. Free Radic Biol Med 11: 239-246, 1991

19. Masisi K, Suidasari S, Zhang P, Okazaki Y, Yanaka N and Kato N: Comparative study on the responses of concentrations of $\mathrm{B}_{6}$-vitamers in several tissues of mice to the dietary level of pyridoxine. J Nutr Sci Vitaminol (Tokyo) 58: 446-451, 2012.

20. Reeves PG, Nielsen FH and Fahey GC Jr: AIN-93 purified diets for laboratory rodents: Final report of the American Institute of Nutrition ad hoc writing committee on the reformulation of the AIN-76A rodent diet. J Nutr 123: 1939-1951, 1993.

21. Coburn SP: A critical review of minimal vitamin B6 requirements for growth in various species with a proposed method of calculation. Vitam Horm 48: 259-300, 1994.

22. Tsuge H: Determination of vitamin B6 vitamers and metabolites in a biological sample. Methods Enzymol 280: 3-12, 1997.

23. Livak KJ and Schmittgen TD: Analysis of relative gene expression data using real-tie quantitative PCR and the 2(-Delta Delta C(T)) Method. Methods 25: 402-408, 2001.

24. Febbraio MA, Mesa JL, Chung J, Steensberg A, Keller C, Nielsen HB, Krustrup P, Ott P, Secher NH and Pedersen BK: Glucose ingestion attenuates the exercise-induced increase in circulating heat shock protein 72 and heat shock protein 60 in humans. Cell Stress Chaperones 9: 390-396, 2004.
25. Pedersen BK: The diseasome of physical inactivity-and the role of myokines in muscle-fat cross talk. J Physiol 587: 5559-5568, 2009.

26. Pedersen BK: Exercise-induced myokines and their role in chronic disease. Brain Behav Immun 25: 811-816, 2011.

27. Powers SK, Ji LL and Leeuwenburgh C: Exercise training-induced alterations in skeletal muscle antioxidant capacity: A brief review. Med Sci Sports Exerc 31: 987-997, 1999.

28. Yang Y, Creer A, Jemiolo B and Trappe S: Time course of myogenic and metabolic gene expression in response to acute exercise in human skeletal muscle. J Appl Physiol (1985) 98: 1745-1752, 2005

29. Samelman TR: Heat shock protein expression is increased in cardiac and skeletal muscles of fischer 344 rats after endurance training. Exp Physiol 85: 92-102, 2000.

30. See K, Yadav P, Giegerich M, Cheong PS, Graf M, Vyas H, Lee SG, Mathavan S, Fischer U, Sendtner M and Winkler C: SMN deficiency alters Nrxn2 expression and splicing in zebrafish and mouse models of spinal muscular atrophy. Hum Mol Genet 23: 1754-1770, 2014.

31. Egginton S: Invited review: Activity-induced angiogenesis. Pflugers Arch 457: 963-977, 2009.

32. Endo N, Nishiyama K, Otsuka A, Kanouchi H, Taga M and Oka T: Antioxidant activity of vitamin B6 delays homocysteine-induced atherosclerosis in rats. Br J Nutr 95: 1088-1093, 2006.

33. Wu CC, Shyu RY, Chou JM, Jao SW, Chao PC, Kang JC, Wu ST, Huang SL and Jiang SY: RARRES1 expression is significantly related to tumour differentiation and staging in colorectal adenocarcinoma. Eur J Cancer 42: 557-565, 2006.

34. Brekken RA, Puolakkainen P, Graves DC, Workman G, Lubkin SR and Sage EH: Enhanced growth of tumors in SPARC null mice is associated with changes in the ECM. J Clin Invest 111: 487-495, 2003.

35. Komatsu SI, Watanabe H, Oka T, Tsuge H, Nii $\mathrm{H}$ and Kato $\mathrm{N}$ : Vitamin B-6-supplemented diets compared with a low vitamin B-6 diet suppress azoxymethane-induced colon tumorigenesis in mice by reducing cell proliferation. J Nutr 131: 2204-2207, 2001.

36. Wruck CJ, Streetz K, Pavic G, Götz ME, Tohidnezhad M, Brandenburg LO, Varoga D, Eickelberg O, Herdegen T, Trautwein C, et al: Nrf2 induces interleukin-6 (IL-6) expression via an antioxidant response element within the IL-6 promoter. J Biol Chem 286: 4493-4499, 2011. 